Article

\title{
Involvement of Acylated Homoserine Lactones (AHLs) of Aeromonas sobria in Spoilage of Refrigerated Turbot (Scophthalmus maximus L.)
}

\author{
Tingting Li ${ }^{1,2}$, Fangchao Cui ${ }^{3}$, Fengling Bai ${ }^{3}$, Guohua Zhao ${ }^{1}$ and Jianrong $\mathrm{Li}^{1,3, *}$ \\ 1 College of Food Science, Southwest University, Chongqing 400715, China; \\ jwltt@dlnu.edu.cn (T.L.); dotanicepl@163.com (G.Z.) \\ 2 College of Life Science, Dalian Nationalities University, Dalian 116029, China \\ 3 College of Food Science and Technology, Bohai University, Jinzhou 121013, China; \\ cfc1031@163.com (F.C.); myan9102@163.com (F.B.) \\ * Correspondence: 13804242235@163.com; Tel./Fax: +86-416-3400-008
}

Academic Editor: Alexander Star

Received: 14 May 2016; Accepted: 8 July 2016; Published: 13 July 2016

\begin{abstract}
One quorum sensing strain was isolated from spoiled turbot. The species was determined by $16 \mathrm{~S}$ rRNA gene analysis and classical tests, named Aeromonas sobria AS7. Quorum-sensing (QS) signals ( $\mathrm{N}$-acyl homoserine lactones (AHLs)) were detected by report strains and their structures were further determined by GC-MS. The activity changes of AHLs on strain growth stage as well as the influence of different culture conditions on secretion activity of AHLs were studied by the punch method. The result indicated that strain AS7 could induce report strains to produce typical phenotypic response. $\mathrm{N}$-butanoyl-DL-homoserine lactone $\left(\mathrm{C}_{4}-\mathrm{HSL}\right), \mathrm{N}$-hexanoyl-DL-homoserine lactone $\left(\mathrm{C}_{6}-\mathrm{HSL}\right), \mathrm{N}$-octanoyl-DL-homoserine lactone $\left(\mathrm{C}_{8}-\mathrm{HSL}\right), \mathrm{N}$-decanoyl-DL-homoserine lactone ( $\left.\mathrm{C}_{10}-\mathrm{HSL}\right), \mathrm{N}$-dodecanoyl-DL-homoserine lactone $\left(\mathrm{C}_{12}-\mathrm{HSL}\right)$ could be detected. The activities of AHLs were density-dependent and the max secretion level was at $\mathrm{pH} 8$, sucrose culture, $1 \% \mathrm{NaCl}$ and $32 \mathrm{~h}$, respectively. The production of siderophore in strain AS7 was regulated by exogenous $\mathrm{C}_{8}-\mathrm{HSL}$, rather than $\mathrm{C}_{6}-\mathrm{HSL}$. Exogenous $\mathrm{C}_{4}-\mathrm{HSL}$ and $\mathrm{C}_{8}-\mathrm{HSL}$ accelerated the growth rate and population density of AS7 in turbot samples under refrigerated storage. However, according to the total viable counts and total volatile basic nitrogen (TVB-N) values of the fish samples, exogenous $\mathrm{C}_{6}-\mathrm{HSL}$ did not cause spoilage of the turbot fillets. In conclusion, our results suggested that QS was involved in the spoilage of refrigerated turbot.
\end{abstract}

Keywords: Aeromonas sobria; siderophore; quorum sensing; spoilage; turbot

\section{Introduction}

Scophthalmus maximus L. is one of the most important farmed fish species in China, Chile and several countries of Europe. Fish are highly perishable products, the spoilage caused by the various biochemical changes naturally occurring as well as due to microbial activities. Microbial spoilage is the most common cause of fish spoilage. Thus, microbial activity is considered to be very important for the manifestation of spoilage. In recent years, the detection of quorum sensing signals in putrid food products has added a new dimension to study the process of food spoilage.

Quorum sensing (QS), a term introduced by Fuqua Winans and Greenberg in 1994 to describe cell-to-cell communication, is a system that allowed bacteria to monitor their population density and control a number of physiological functions by releasing and receiving of signal molecules, called autoinducers (AIs) [1]. N-acyl-homoserine lactones (AHLs) are the most common AIs and are generally specific to Gram-negative bacteria [2]. The regulation of phenotypes such as swarming, 
virulence and biofilm formation, is dependent on population density, which is synchronized by the signal molecules [3-6]. The most important study of QS focused on the AHL regulating role in bacterial pathogenesis [2,7]. To date, food spoilage via microbial regulation by QS, an event leading to severe economic losses as well as public health problems, receives more attention from researchers. Some studies have identified biofilm formation regulated by QS in Aeromonas hydrophila, Pseudomonas fluorescens and Serratia liquefaciens [8,9].

The detection of AHLs is a key procedure in the QS system. By typical phenotypic response, such as $\beta$-galactosidase activity, bioluminescence, or violacin production, report stains are generally used to screen for AHL production [10,11] or in synchronous combination [12]. Each induced strain responds to a different scope of AHLs, but the results may be false positive. Thin-layer chromatography (TLC) is a fast and cheap method to detect the types of AHLs by covering the monitoring bacteria with plates and separating the extracts of bacteria as well as AHL standards [13]. Now, the detection of AHLs is more sensitive and reliable under the different circumstances. High-performance liquid chromatography-(tandem) mass-spectrometry (HPLC-(MS)/MS) and gas chromatography-mass spectrometry (GC-MS) are utilized for qualitative and quantitative analysis. LC-MS/MS applied for quantitative AHLs was validated by Ortori [14]. Zhu [15] reported a GC-MS method for AHL detection and revealed three AHLs from the extract of two strains isolated from refrigerated shrimp.

Aeromonas sobria, a Gram-negative, motile, flagellated, facultative anaerobic bacterial, is an opportunistic pathogen of animals, aquatics, and humans [16-19]. In recent years, research on QS in Aeromonas spp. has concentrated on Aeromonas hydrophilia and QS regulation of biofilm formation, virulence factors, protease activity and motility [20-22].

In this study, gas chromatography-mass spectrometry (GC/MS) was utilized to detect AHLs produced by A. sobria strain AS7, which was isolated from vacuum-packed, refrigerated putrid turbot. Meanwhile, the effect of environmental conditions on the production of AHLs, as well as AHL-production kinetics was studied by agar well diffusion assay. Furthermore, the exogenous autoinducers were added to the culture medium of AS7 and inoculated AS7 to sterile fish fillets. The purpose of the present work was to elucidate whether bacterial signals (AHLs) and AHL-dependent regulation contribute to the spoilage of fish.

\section{Materials and Methods}

\subsection{Materials and Bacterial Strains}

Live turbot were collected from a local aquatic products market (Jinzhou, China) and transferred to the laboratory with oxygenated water. The fish were killed and rinsed with sterile water. Then, the sample was vacuum-packed and refrigerated at $-2{ }^{\circ} \mathrm{C}$ for 28 days. $\mathrm{N}$-butanoyl-DL-homoserine lactone ( $\left.\mathrm{C}_{4}-\mathrm{HSL}\right), \mathrm{N}$-hexanoyl-DL-homoserine lactone ( $\left.\mathrm{C}_{6}-\mathrm{HSL}\right), \mathrm{N}$-octanoyl-DL-homoserine lactone ( $\left.\mathrm{C}_{8}-\mathrm{HSL}\right), \mathrm{N}$-decanoyl-DL-homoserine lactone $\left(\mathrm{C}_{10}-\mathrm{HSL}\right), \mathrm{N}$-dodecanoyl-DL-homoserine lactone $\left(\mathrm{C}_{12}-\mathrm{HSL}\right), \mathrm{N}$-tetradecanoyl-DL-homoserine lactone $\left(\mathrm{C}_{14}-\mathrm{HSL}\right)$ were purchased from Sigma-Aldrich (Poole, UK). Other reagents used in this study were commercially available and of analytical grade. Chromobacterium violaceum CV026 and Agrobacterium tumefaciens A136 were stored at our laboratory.

\subsection{Isolation and Identification of Bacterial Strains}

Ten grams of the samples were mixed with $90 \mathrm{~mL}$ sterile normal saline and flapped in BagMixer (Interscience, St. Nom, France) for $1 \mathrm{~min}$. Then, the treated sample was continuously diluted and counted on Plate Count Agar (PCA, Aoboxing Bio-Tech, Beijing, China) and incubated at $28{ }^{\circ} \mathrm{C}$ for $48 \mathrm{~h}$. After $48 \mathrm{~h}$, all obviously distinct bacterial colonies were appraised and each colony was streaked onto Aeromonas Selective Medium Base (Ryan) followed by incubation at $28{ }^{\circ} \mathrm{C}$ for $24 \mathrm{~h}$. The color, outline, size and other optical properties of the colonies were observed and recorded. The VITEK-2 Compact system (BioMerieux, Marcy l'Etoile, France) was used to identify the single colony [23]. Further study on the colony was validated with 16S rRNA PCR 
using the forward primer 27F ( $5^{\prime}$-AGAGTTTGATCCTGGCTCAG- $3^{\prime}$ ) and the reverse primer 1492R (5'-ACGGCTACCTTGTTACGACTT-3') amplify the 16S rRNA gene [24]. The gene sequences were analyzed by comparing the closely related sequences by BLASTN program in the GenBank database and phylogenetic analyses using MEGA 5.0 software.

\subsection{AHL Detection of the Isolated Strain}

The AHL molecule side chain length varies from short chain (C4) to long chain (C18) carbon chains. The strain to be tested for reaction of $C$. violaceum CV026 with the LuxR homologue, CviR, which regulates the production of a purple pigment when induced by particular AHLs, was parallel streaked on LB agar plate, which rapidly screened for short chain AHL production [13]. The presence of long chained AHLs detected by A. tumefaciens A136, which carries a lacZ fusion to traI and produces a blue color in the presence of 5-bromo-4-chloro-3-indoyl- $\beta$-D-galactopyranoside ( $X$-Gal), was done in a similar method supplementing with $20 \mu \mathrm{L}$ X-Gal $(20 \mathrm{mg} / \mathrm{mL})$ [12]. $\mathrm{C}_{4}-\mathrm{HSL}$ and $\mathrm{C}_{6}-\mathrm{HSL}$ were used as positive controls for CV026 and A136, respectively. Negative controls were the monitor strains themselves.

\subsection{Extraction of AHLs}

In addition, $100 \mathrm{~mL}$ culture was centrifuged at 10,000 rpm for $10 \mathrm{~min}$ then extracted with an equivalent volume of ethyl acetate $(0.1 \%(\mathrm{v} / \mathrm{v})$ glacial acetic acid). The mixture was shaken adequately for $30 \mathrm{~s}$ and stayed for layer. This process was repeated three times before the ethyl acetate was removed and another $100 \mathrm{~mL}$ ethyl acetate was added. Then, the whole extraction process was repeated three times and the whole ethyl acetate fraction was mixed. The combined ethyl acetate fractions were evaporated with rotary evaporators $\left(35^{\circ} \mathrm{C}, 150 \mathrm{rpm}\right)$ to dryness and redissolved in $1 \mathrm{~mL}$ methyl alcohol. The extracts were stored in sterile microcentrifuge tubes at $-20^{\circ} \mathrm{C}$.

\subsection{AHL-Production Kinetics}

The value of AHLs was determined by the agar diffusion method using CV026. A preculture was done in LB medium and grown for $12 \mathrm{~h}$ at $28^{\circ} \mathrm{C}$, and $100 \mu \mathrm{L}$ was diluted to $100 \mathrm{~mL}$ of LB medium. The culture was grown at $28{ }^{\circ} \mathrm{C} 160 \mathrm{rpm}$ and was monitored by $\mathrm{OD}_{600}$ determinations. In addition, a $100 \mathrm{~mL}$ sample was withdrawn every four hours and centrifuged at 10,000 rpm for $10 \mathrm{~min}$. The supernatant was used to analyze AHL-content in the well-diffusion assay [25]. Each well was supplemented with $200 \mu \mathrm{L}$ supernatant and was grown for $48 \mathrm{~h}$ at $28^{\circ} \mathrm{C}$. Diameters of induced zones were measured and recorded.

\subsection{Effect of Several Conditions on AHL Production in AS7}

The effect of the carbon source on AHL production was studied in AB medium [26] supplemented with casamino acids (CAA, $0.5 \%$ ) and $0.5 \%$ of one of the following carbon sources: glucose, sucrose, fructose, xylose, lactose or maltose. The influence of $\mathrm{pH}$ value was studied by Trypticase Soy Broth (TSB) media to $\mathrm{pH} 4,5,6,7,8$ or 9 by mixing different volumes of phosphate buffer. The effect on AHL production by altering salt concentrations was studied in LB medium with $0.5 \%, 0.7 \%, 1.0 \%, 2.0 \%$, $3.0 \%, 4.0 \%$ or $5.0 \% \mathrm{NaCl}$. Pre-cultures for experiments carried out at $28{ }^{\circ} \mathrm{C}$ were grown in TSB medium for $12 \mathrm{~h}$ and were diluted as 1:1000 to inoculate into various media. They were grown for $24 \mathrm{~h}$ at $28^{\circ} \mathrm{C}$ $160 \mathrm{rpm}$ and determined $\mathrm{OD}_{600}$. In addition, $100 \mathrm{~mL}$ solution was centrifuged at 10,000 rpm for $10 \mathrm{~min}$ and the supernatant was stored at $-20^{\circ} \mathrm{C}$.

\subsection{AHL Identification via Gas Chromatography-Mass Spectrometry (GC-MS)}

Analyses were performed using a GC-MS Agilent 7890N/5975 (Agilent, Palo Alto, CA, USA) according to Zhu [15] with some modifications. All sample injections were done in the split mode (50:1) into an HP-5 MS capillary column (30 m length $\times 0.25 \mathrm{~mm}$ internal diameter $\times 0.25 \mu \mathrm{m}$ film thickness) 
(Agilent, Palo Alto, CA, USA). Helium was used as the carrier gas at a flow rate of $1 \mathrm{~mL} / \mathrm{min}$. The GC injector temperature was $200{ }^{\circ} \mathrm{C}$ and the oven temperature was programmed as follows: $150{ }^{\circ} \mathrm{C}$ ramped at $10{ }^{\circ} \mathrm{C} / \mathrm{min}$ to $220^{\circ} \mathrm{C}$, and ramped at $5^{\circ} \mathrm{C} / \mathrm{min}$ to $250{ }^{\circ} \mathrm{C}$, then ramped at $0.5^{\circ} \mathrm{C} / \mathrm{min}$ to $252.5^{\circ} \mathrm{C}$. Mass spectrometry conditions were as follows: electron ionization source was set to $70 \mathrm{eV}$, MS Quad $150{ }^{\circ} \mathrm{C}$, emission current $500 \mu \mathrm{A}$, MS Source $230{ }^{\circ} \mathrm{C}$. Data were acquired by either full-scan mode $(m / z$ 35-800) and in selected ion monitoring (SIM) mode $(m / z 143)$.

\subsection{Siderophore Assay}

Siderophore production was detected on solid media using Chrome-Azurol-S CAS-agar [27] (NC Pharmculture CO., Ltd, Beijing, China) with some modifications. To prepare 1 L of blue agar, $60.50 \mathrm{mg}$ CAS was dissolved in $50 \mathrm{~mL}$ distilled water and mixed with $10 \mathrm{~mL}$ iron(III) solution (1 mM $\mathrm{FeCl}_{3} \cdot 6 \mathrm{H}_{2} \mathrm{O}, 10 \mathrm{mM} \mathrm{HCl}$ ). Under mixing this solution was slowly added to $72.90 \mathrm{mg}$ hexadecyl trimethyl ammonium bromide (HDTMA) dissolved in $40 \mathrm{~mL}$ distilled water. The composite dark blue liquid was autoclaved at $121^{\circ} \mathrm{C}, 15 \mathrm{~min}$, which was keeping the standby as the CAS assay solution. Also autoclaved was $30 \mathrm{~mL}$ casamino acids (10\%), after cooling to $50{ }^{\circ} \mathrm{C}$, stirring with $1 \mathrm{~mL} \mathrm{CaCl}_{2}$ (1 mM), $20 \mathrm{~mL} \mathrm{MgSO} 4 \cdot 7 \mathrm{H}_{2} \mathrm{O}(1 \mathrm{mM}), 10 \mathrm{~mL}$ glucose $(20 \%)$ as a carbon source, $15.00 \mathrm{~g}$ agar, $30.24 \mathrm{~g}$ 1,4-Piperazinediethanesulfonic acid (Pipes), and $12.00 \mathrm{~g}$ of a $50 \%(w / w) \mathrm{NaOH}$ solution to raise the $\mathrm{pH}$ to the $\mathrm{pKa}$ of Pipes (6.8). Then the cultures were heated to $121^{\circ} \mathrm{C}$ and maintained 15 min by autoclaved. After cooling to $60^{\circ} \mathrm{C}$, stirring the CAS assay solution mentioned above, the solution was slowly added by edgeways conical flask, with enough agitation without generation of foam. Each plate contained $20 \mathrm{~mL}$ of blue agar with punching by Oxford cup (autoclaved). These blue agars were used to detect siderophores. Exogenous autoinducers were added as follows: $\mathrm{C}_{6}-\mathrm{HSL}, 10,20$ and $40 \mu \mathrm{M}$; $\mathrm{C}_{8}-\mathrm{HSL}, 10,20$ and $40 \mu \mathrm{M}$. An equal volume of methyl alcohol was used as the negative control.

\subsection{Fish Spoilage Assays}

Sterile turbot fillets were made according to Herbert [28] with some modifications. Live turbot were killed and the fish fillets were washed by distilled water and drained off in the Clean Bench (Shiwei Ke Environmental Science and Technology Co., Ltd, Suzhou, China), then sprayed with 75\% alcohol on the surface and skimmed over the outer flame of alcohol lamp. In order to confirm the fish fillets were sterile, samples were cultured in PCA to detect the total viable counts below $2.0 \mathrm{log} \mathrm{cfu} / \mathrm{g}$.

Prior to inoculation of fish, the strain AS7 was inoculated in $10 \mathrm{~mL}$ TSB and incubated overnight at $28^{\circ} \mathrm{C}$ with shaking at $160 \mathrm{rpm}$. Then, the cultures were centrifuged at 10,000 rpm for $10 \mathrm{~min}$, washed, and resuspended in sterile $0.85 \%$ physiological saline to produce a final optical density at $600 \mathrm{~nm}$ $\left(\mathrm{OD}_{600}\right)$ of 1.0 [20]. Exogenous autoinducers were added as follows: $\mathrm{C}_{4}-\mathrm{HSL}, \mathrm{C}_{6}-\mathrm{HSL}$ and $\mathrm{C}_{8}-\mathrm{HSL}$ $20 \mu \mathrm{M}$, respectively. An equal volume of methyl alcohol was used as the negative control. The sterile fish fillets were dipped in the bacterial suspension for $2 \mathrm{~s}$, then packaged with sterile PVC bag at $4{ }^{\circ} \mathrm{C}$.

\section{Results and Discussion}

\subsection{Identification of Bacteria Isolates}

A pure strain AS7 was obtained after several successive streakings. Physically, the strain AS7 colonies were round, the surface wet, uplifted, transparent, edge neat little colony, and Gram-negative. Strain AS7 was identified using the Vitek-2 Compact system (bioMerieux, Marcy l'Etoile, France), which showed 99\% similarity to Aeromonas sobria. Physiological and biochemical characters of strain AS7 were described in detail (Table 1). Strain AS7 was validated with 16S rRNA gene nucleotide analysis for further study, and the result was based on GenBank database and phylogenetic analysis of the $16 \mathrm{~S}$ rRNA on MEGA (Figure 1), where the evolutionary history was deduced using the Neighbor-Joining method [29]. The percentage of repeat trees in which the related taxa clustered together in the bootstrap test (1000 repeats) was indicated next to the branches [30]. The evolutionary distances were calculated using the Maximum Composite Likelihood method [31] and were in the units of the number of 
base replacements per site. Our phylogenetic analysis results revealed that strain AS7 belonged to Aeromonas sobria.

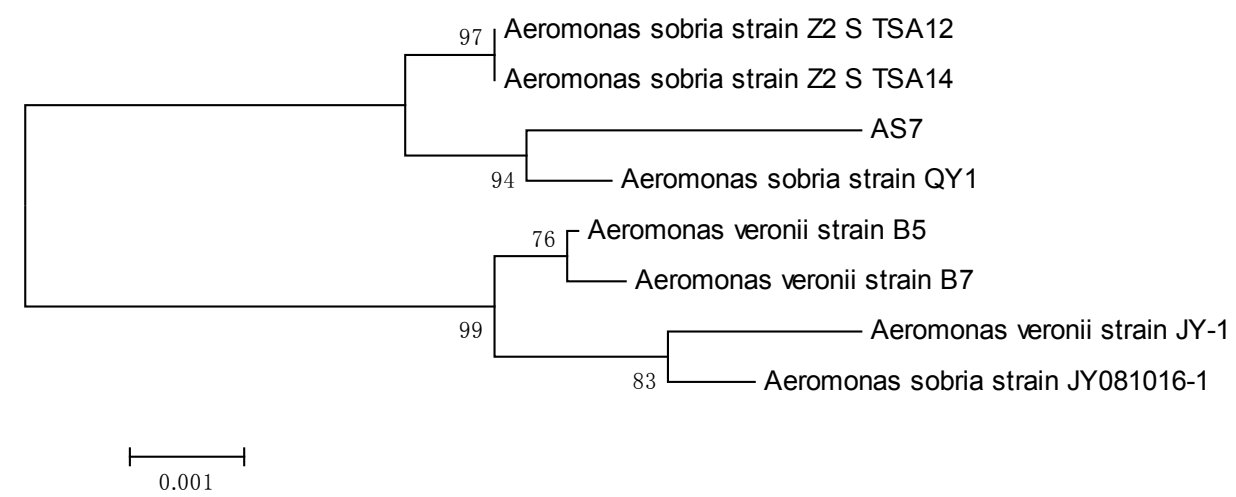

Figure 1. The phylogenetic relationships of strain AS7 and other Aeromona.

\subsection{Detection of AHLs}

AHLs produced by A. sobria strain AS7 were detected by using A. tumefaciens A136 and C. violaceum CV026. A. tumefaciens A136 carries a plasmid with PtraI-lacZ fusion and produces a blue color by degrading the $\mathrm{X}-\mathrm{Gal}$ in response to long chained AHLs [12,32]. The CviR of C. violaceum CV026 regulates the production of violacein when induced by short chained AHLs [12,33]. Strain AS7 showed positive results by inducing a blue color and violacein production in A. tumefaciens A136 and C. Violaceum CV026, respectively, suggesting both short and long-chained AHLs are produced by AS7 (Figure 2).

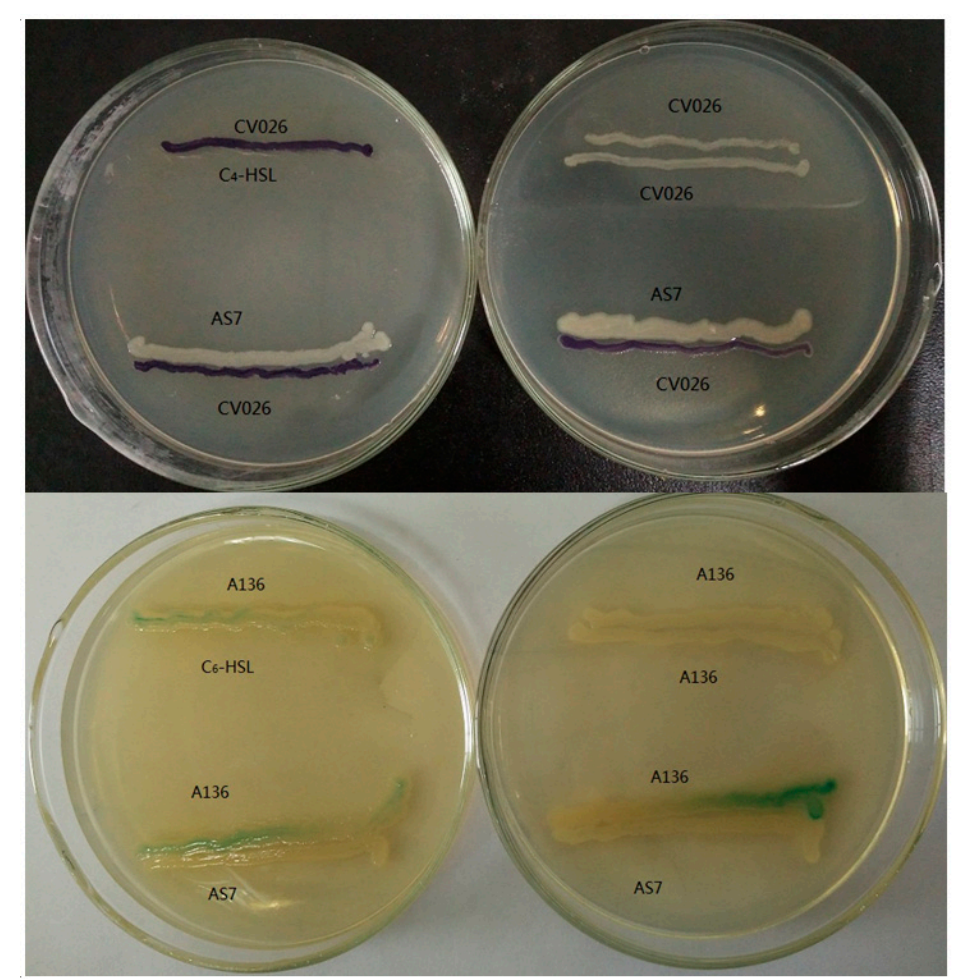

Figure 2. Streak assays for the production of short chain ( $N$-acyl homoserine lactones (AHLs)) in test strain (screening for AHLs production using C. violaceum CV026 and A. tumefaciens A136 cross parallel streaking with $\mathrm{C}_{4}-\mathrm{HSL}\left(\mathrm{C}_{4}\right.$-homoserine lactones) and $\mathrm{C}_{6}-\mathrm{HSL}$ as positive control, respectively. Negative controls were the monitor strains themselves.). 


\subsection{Short Chain AHL Production Kinetics}

Short chain AHL-production was measured through a well-diffusion assay using C. violaceum CV026 as the monitor strain and the concentration of short chain AHLs in the supernatant was estimated by measuring the diameter of the induced zone. Strain AS7 has a stronger ability to secrete AHLs from $12 \mathrm{~h}$ to $44 \mathrm{~h}$, and the concentration of AHLs was at a high level during this period (Figure $3 \mathrm{a}$ ). At logarithmic phase of strain AS7 (4-16 h), the concentration increased rapidly as synchronous as the content of short chain AHLs-signal molecules (Figure 3b). Then, the stationary phase came and the content of short chain AHLs maintained a high level, and the concentration of signal molecules achieved the highest level at $32 \mathrm{~h}$ and was in accordance with bacterial density. The production of short chain AHLs showed a decrease trend after the initial increase with the extension of incubation time and presented the density dependence. This might be that the bacteria began to enter the decline period.
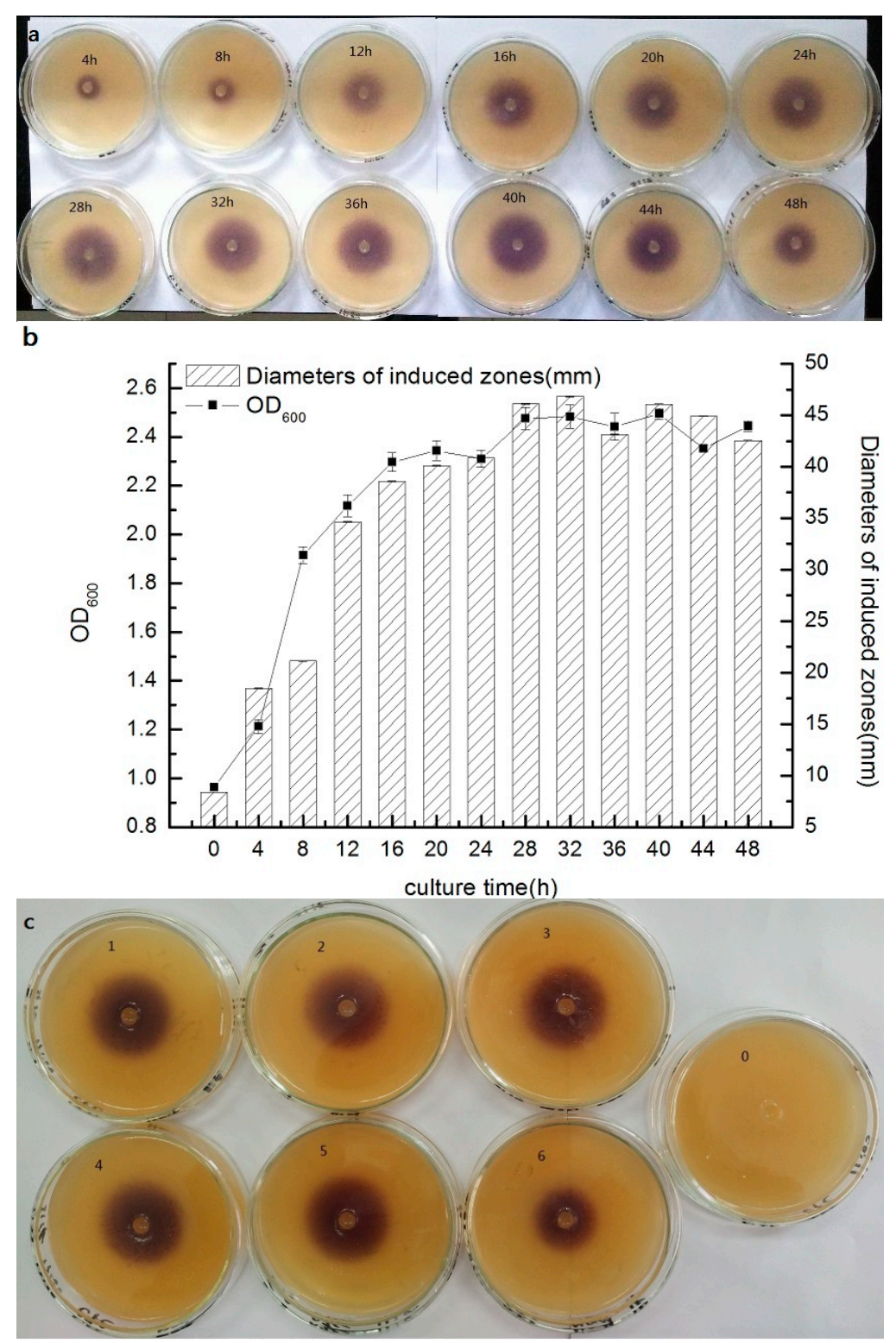

Figure 3. Cont. 
d
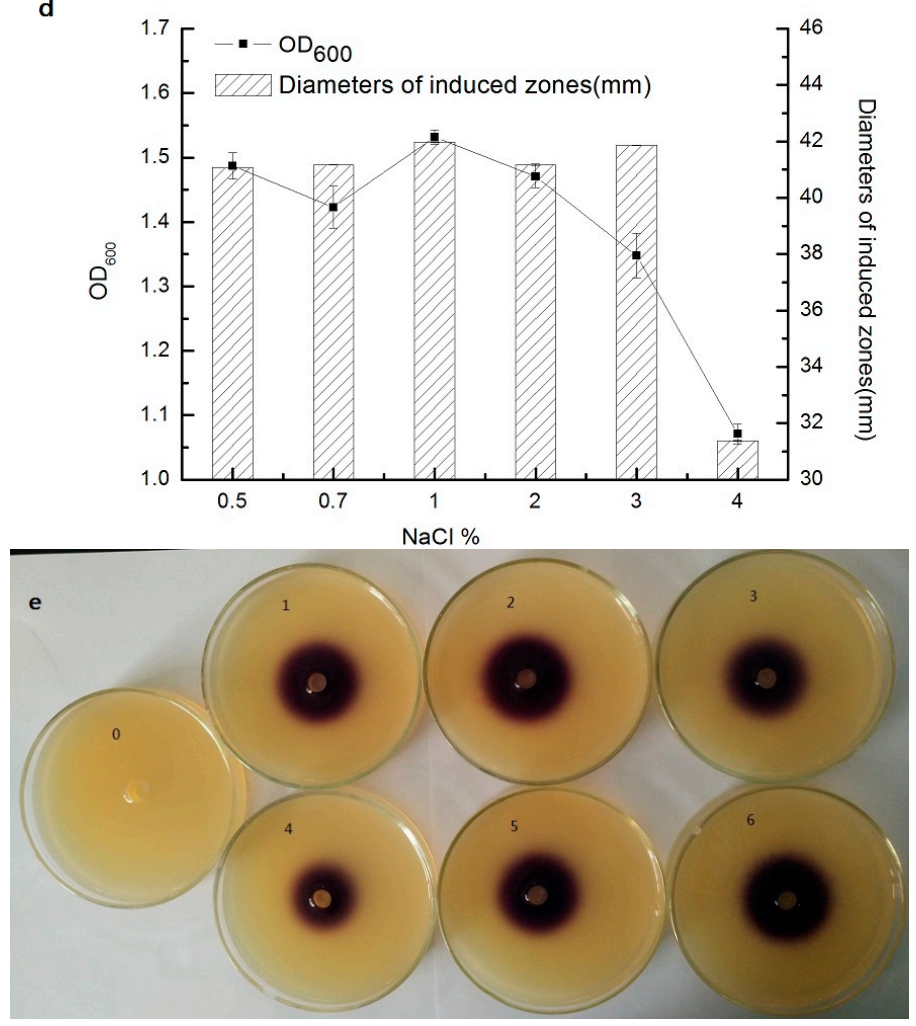

f
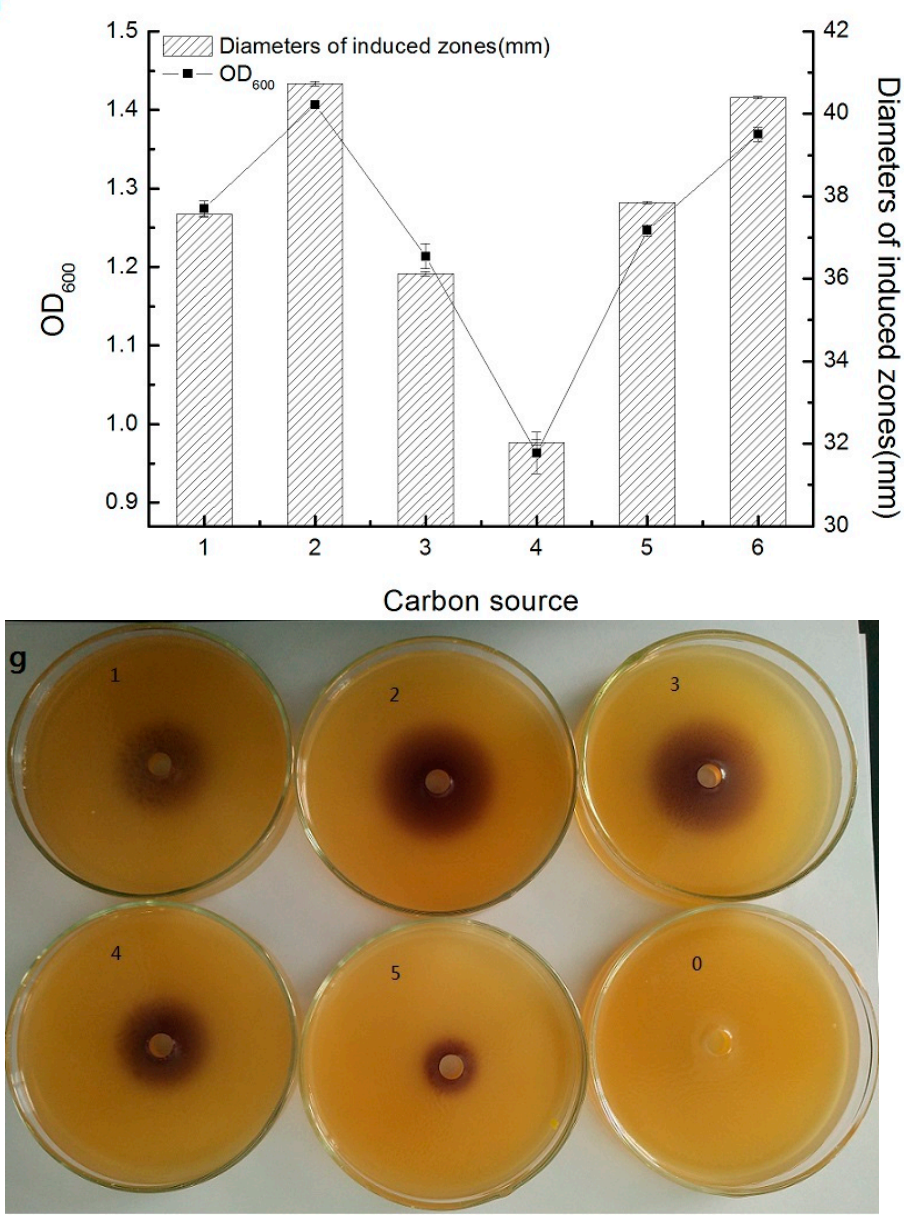

Figure 3. Cont. 


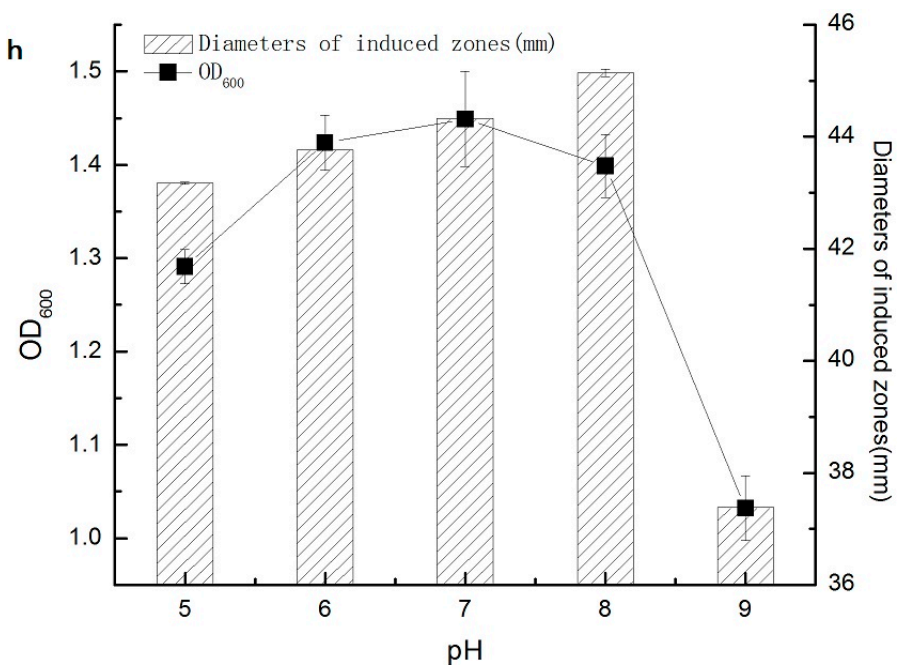

Figure 3. Relationship between growth kinetics and short chain AHL secretion under different culture time of strain AS7 and effect of different conditions on short chain AHLs production by AS7 (a): Agar well diffusion assay to detect AHLs secretion under different culture time; (b): the graph of relationship between kinetics and AHLs; (c,d): $\mathrm{NaCl}$ concentration 0: blank control, 1: $\mathrm{NaCl} 0.5 \%, 2: \mathrm{NaCl} 0.7 \%$, 3: $\mathrm{NaCl} 1 \%, 4: \mathrm{NaCl}$ 2\%, 5: $\mathrm{NaCl} 3 \%, 6: \mathrm{NaCl} 4 \%$; (e,f): carbon source 0: blank control, 1: glucose, 2: sucrose, 3: frutose, 4: xylose, 5: lactose, 6: maltose; (g,h): 0: blank control, 1: pH 5, 2: pH 6, 3: pH 7, 4: $\mathrm{pH}$ 8, 5: $\mathrm{pH} 9$.

\subsection{Effect of Different Conditions on Short Chain AHL Production by Strain AS7}

Figure $3 \mathrm{c}$ showed the results for AHL production by strain AS7 under different contents of sodium chloride. In general, the results presented a prominent relationship between population levels and AHL production (Figure 3d). Our data was in accordance with previous reports about AHL QS systems in Aeromonas spp. [34]. At 4\% (w/v) NaCl, the concentration of AHLs showed a significant decline compared to the other concentrations, which was correlated with a low colony count. When the concentration of $\mathrm{NaCl}$ was at $5 \%$, the strain AS7 could not grow up. This might be that the high concentration of $\mathrm{NaCl}$ inhibited the growth of strain AS7. However, at low concentrations $(0.5 \%-2 \%)$, the production of AHLs was at a high level and showed no obvious change. The production of signal molecules was about the maximum at $1 \% \mathrm{NaCl}$. This was probably because salinity controlled the production of AHLs. Jahid [8] reported that salinity could influence $\mathrm{C}_{4}-\mathrm{HSL}, \mathrm{C}_{6}-\mathrm{HSL}$, as well as biofilms, exoproteases and motility of $A$. hydrophila isolated from surface water. Medina-Martinez [34] reported that $3 \% \mathrm{NaCl}$ completely inhibited AHL production of A. hydrophila isolated from food samples, which was accordance with our results.

The effect of different carbon source on short chain AHL production for strain AS7 was shown in Figure 3e. The results showed a significant relationship between the concentration of strain AS7 and the production of signal molecules (Figure 3f). The ability of carbon sources to influence the secreted AHLs of strain AS7 was as follows: sucrose $>$ maltose $>$ glucose $>$ lactose $>$ fructose $>$ xylose. Sucrose was the best carbon source for the growth of strain AS7 and xylose was not conducive to the production of AHLs. Flodgaard [35] reported no effect on 3-oxo- $\mathrm{C}_{6}-\mathrm{HSL}$ secretion of S. proteamaculans by change of carbon sources. However, the growing environments of different species were variant. Strain AS7 could not make full use of xylose to increase the density and then influence the secretion of AHLs, which was consistent with our results that strain AS7 could use sucrose, maltose and glucose, but xylose was negative (Table 1).

With regard to AHL production at different $\mathrm{pH}$ values, AHL secretion was correlated with total viable count (Figure 3g,h). At pH 8, the concentration of AHLs was at the highest level; at $\mathrm{pH} 4$, strain AS7 could not survive. Acid conditions ( $\mathrm{pH} 5$ and 6) and neutral environment were not significant to the production of AHLs. Acid conditions were lower than the neutral environment and 
the lower the $\mathrm{pH}$ was, the lower the AHL production. This might be that an adverse environmental condition (weak acid condition) could not lead to the effective growth of AS7, while at pH 9, a sharp drop of signal molecules was presented. Our data agreed with previous studies that AHLs were unstable at alkaline conditions [35,36].

Table 1. Physiological and biochemical characters of the AS7 strains.

\begin{tabular}{cccccc}
\hline Item & Phenotype & Item & Phenotype & Item & Phenotype \\
\hline APPA & + & PyrA & - & dCEL & - \\
$\mathrm{H}_{2} \mathrm{~S}$ & - & AGLTp & - & GGT & - \\
BGLU & - & dMAN & + & BXYL & - \\
ProA & - & PLE & - & URE & - \\
SAC & + & dTRE & + & MNT & - \\
ILATk & - & SUCT & + & AGAL & - \\
GlyA & - & LDC & - & CMT & + \\
O129R & + & IMLTa & + & ILATa & - \\
ADO & - & IARL & - & BGAL & + \\
BNAG & + & dGLU & + & OFF & + \\
dMAL & + & dMNE & + & BAIap & - \\
LIP & - & TyrA & + & dSOR & - \\
dTAG & - & CIT & - & 5KG & - \\
AGLU & - & NAGA & - & PHOS & - \\
ODC & - & IHISa & - & BGUR & - \\
GGAA & + & ELLM & + \\
\hline \multicolumn{7}{c}{ Notes: “+ for positive, “ - for negative. }
\end{tabular}

\subsection{GC-MS Analysis of AHLs in Extracts of Bacterial Cultures}

The GC-MS method was used to further verify the AHL production. All AHLs are characterized by a homoserine lactone moiety and a fatty acyl group whose members have various lengths, ranging from 4 to 14 carbons. The fragments of AHL standards were listed in Table 2 . The ion at $m / z 143$ was chosen as the prominent fragment to detect extracted samples [37]. Meanwhile, a standard mixture of AHLs was detected and the retention times of $\mathrm{C}_{4}-\mathrm{HSL}, \mathrm{C}_{6}-\mathrm{HSL}, \mathrm{C}_{8}-\mathrm{HSL}, \mathrm{C}_{10}-\mathrm{HSL}, \mathrm{C}_{12}-\mathrm{HSL}$, and $\mathrm{C}_{14}$-HSL were $4.172 \mathrm{~min}, 5.956 \mathrm{~min}, 7.942 \mathrm{~min}, 10.239 \mathrm{~min}, 12.836 \mathrm{~min}$, and $16.044 \mathrm{~min}$, respectively (Figure 4a). According to retention time and prominent fragments ( $m / z$ 143), $\mathrm{C}_{4}-\mathrm{HSL}, \mathrm{C}_{6}-\mathrm{HSL}, \mathrm{C}_{8}-\mathrm{HSL}$, $\mathrm{C}_{10}-\mathrm{HSL}$ and $\mathrm{C}_{12}-\mathrm{HSL}$ were present in the extracted samples (Figure $4 \mathrm{~b}$ ). The detection of AHLs, peculiarly $\mathrm{C}_{6}-\mathrm{HSL}$, was in agreement with reported studies as the AHL QS in the Aeromonas species that significantly produced $\mathrm{C}_{6}-\mathrm{HSL}$ [38]. Cataldi [37] demonstrated that Aeromonas hydrophila and Aeromonas salmonicida synthesized $\mathrm{C}_{8}-\mathrm{HSL}, \mathrm{C}_{12}-\mathrm{HSL}, \mathrm{C}_{14}-\mathrm{HSL}$ and $\mathrm{C}_{8}-\mathrm{HSL}, \mathrm{C}_{10}-\mathrm{HSL}, \mathrm{C}_{12}-\mathrm{HSL}$, $\mathrm{C}_{14}$-HSL as major AHLs, respectively. Our results suggested that strain AS7 could produce five types of AHLs, with $\mathrm{C}_{8}-\mathrm{HSL}$ and $\mathrm{C}_{10}-\mathrm{HSL}$ being the major AHLs in particular. Although Aeromonas spp., such as, Aeromonas hydrophila and Aeromonas salmonicida, were studied extensively, the research on the types of AHLs secreted by Aeromonas sobria was reported firstly in detail.
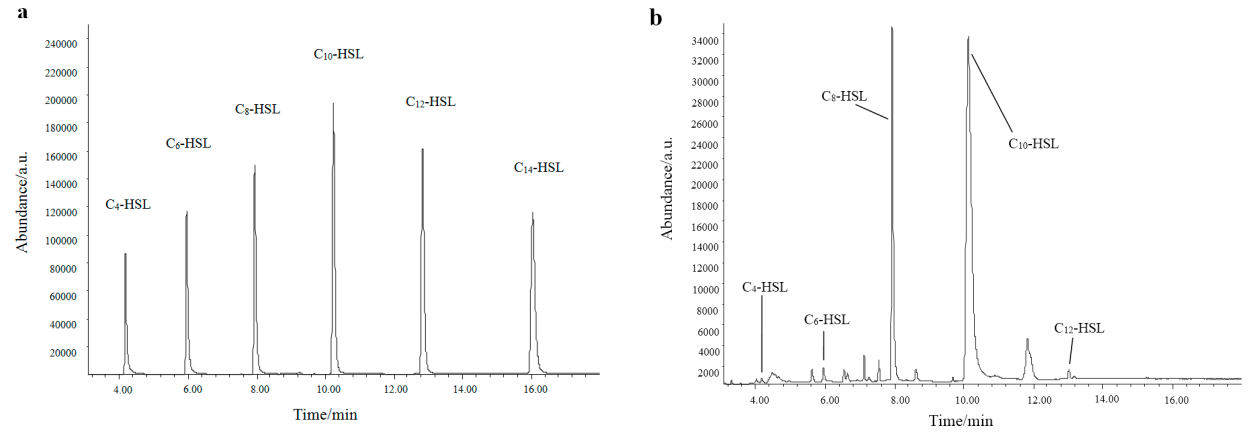

Figure 4. GC-MS chromatogram in SIM mode at $m / z 143$ of a standard mixture of AHLs (a) and an extract of cell-free supernatant of AS7 (b). 
Table 2. The SIM parameter of six kinds of AHLs.

\begin{tabular}{ccc}
\hline AHLs & Fragment & Retention Times/min \\
\hline $\mathrm{C}_{4}-\mathrm{HSL}$ & $32,43.1,57.1,71.1,83,102.1,125.1,143,153.1,171.1$ & 4.172 \\
$\mathrm{C}_{6}-\mathrm{HSL}$ & $32,43.1,56.1,71.1,83,99.1,102.1,125,143.1,156.1$ & 5.956 \\
$\mathrm{C}_{8}$-HSL & $32,43.1,57.1,69.1,83.1,102.1,125.1,143.1,156.1,207$ & 7.942 \\
$\mathrm{C}_{10}-\mathrm{HSL}$ & $32,43.1,57.1,69,83.1,102.1,125,143,156.1,207$ & 10.239 \\
$\mathrm{C}_{12}-\mathrm{HSL}$ & $32,43.1,57.1,71.1,83,102.1,125.1,143,156.1,207$ & 12.836 \\
$\mathrm{C}_{14}-\mathrm{HSL}$ & $32,43.1,57.1,69,83.1,102.1,125.1,143,157.1$ & 16.044 \\
\hline
\end{tabular}

\subsection{The Regulation of Siderophore Secretion by QS in AS7}

Levels of siderophore production were tested on CAS-plates. Siderophores are small, iron-chelating molecules secreted by microorganisms to scavenge iron [39]. The color of the CAS complex, ferric iron and hexadecyltrimethylammonium (HDTMA), changed from blue to orange when iron was removed by siderophores. The diameters of orange halos were measured to determine the relative amount of siderophores produced [40]. Iron is essential for the growth of most microorganisms and is used in bacterial respiration (as electron shuttler) and in redox enzymes. Due to the high oxidative power of $\mathrm{Fe}^{3+}$, iron is mostly bound in insoluble complexes in the environment and in mammals and plants. Most microorganisms have therefore developed highly specific iron chelating systems, and they often produce siderophores, which are iron chelators secreted by the cell. All facultative anaerobic and aerobic bacteria require iron for growth. In order to compete, siderophores are produced under iron-limiting conditions by some bacteria. The production of siderophore is conducive for bacteria to maintain a high level density and have a population-wide benefit. As shown in Figure 5a, $\mathrm{C}_{6}$-HSL exerted no significant effect on the content of siderophores. However, $\mathrm{C}_{8}-$ HSL significantly increased the production of siderophores (Figure 5b), meanwhile having an obvious correlation between the production of siderophores and the additive amount of $\mathrm{C}_{8}-$ HSL $(p<0.01)$ (Figure 5c). $\mathrm{C}_{8}-\mathrm{HSL}$ could regulate the production of siderophores and present positive correlation in strain AS7. These results were in accordance with our previous study about the AHLs of strain AS7, which showed that $\mathrm{C}_{8}-\mathrm{HSL}$ was the maximum in extracted samples.

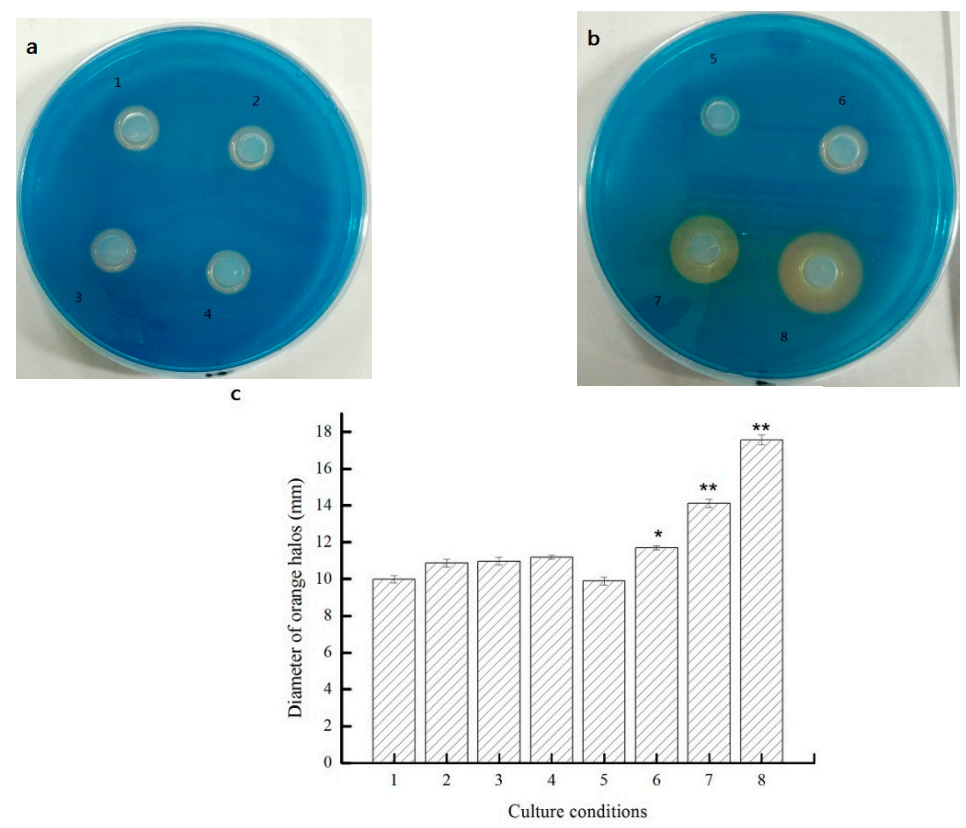

Figure 5. The effects of exogenous autoinducers on siderophore formation in AS7 (c) - (a): (2), $10 \mu \mathrm{M}$ $\mathrm{C}_{6}-\mathrm{HSL}$; (3), $20 \mu \mathrm{M} \mathrm{C}_{6}-\mathrm{HSL}$; (4), $40 \mu \mathrm{M} \mathrm{C}_{6}-\mathrm{HSL}$ and (b): (6), $10 \mu \mathrm{M} \mathrm{C}_{8}-\mathrm{HSL}$; (7), $20 \mu \mathrm{M} \mathrm{C} \mathrm{C}_{8}-\mathrm{HSL}$; (8), $40 \mu \mathrm{M} \mathrm{C}_{8}-$ HSL. (1) and (5) was as the control. Data were presented as the mean \pm standard deviation $\left(n=3{ }^{*} p<0.05 ;{ }^{* *} p<0.01\right)$. 


\subsection{The Effect of QS on the Spoilage Process}

Levels of total viable counts and TVB-N values are important quality parameters for evaluating the process of fish spoilage. As shown in Figure $6 \mathrm{a}, \mathrm{b}$, exogenous $\mathrm{C}_{4}-\mathrm{HSL}$ and $\mathrm{C}_{8}-\mathrm{HSL}$ significantly stimulated the production of TVB-N $(p<0.01)$, while no significant effect of exogenous $\mathrm{C}_{6}-\mathrm{HSL}$ was observed $(p>0.05)$. Total viable counts showed the similar results with TVB-N. Exogenous $\mathrm{C}_{6}-\mathrm{HSL}$ presented no significant effect on the fish fillet spoilage $(p>0.05)$. Bruhn [41] reported that AHLs did not influence the spoilage of vacuum-packed meat. The specific signaling molecule of AHLs might not the key factor of regulation, such as $\mathrm{C}_{6}-\mathrm{HSL}$ for strain AS7, while $\mathrm{C}_{4}-\mathrm{HSL}$ and $\mathrm{C}_{8}-\mathrm{HSL}$ enhanced total viable counts of fish-related bacteria in vitro. $\mathrm{C}_{4}-\mathrm{HSL}$ and $\mathrm{C}_{8}-\mathrm{HSL}$ regulated the secretion of proteases [15], the proteins were rapidly decomposed by the proteases and produced a putrid odor. Zhang [42] reported that addition of exogenous AHLs and QSI decreased the specific protease activity both of the Serratia A2 and Aeromonas B1 and exogenous AHLs enhanced the biofilm formation in Aeromonas B1. The effects of QS signaling molecules on the growth kinetics of spoilage in foods had been reported previously. Christensen [43] reported that $N$-( $\beta$-ketocaproyl)-L-homoserine lactone regulated the production of proteases. The different effects of $\mathrm{C}_{4}-\mathrm{HSL}, \mathrm{C}_{6}-\mathrm{HSL}$, and $\mathrm{C}_{8}-\mathrm{HSL}$ on TVB-N production and total viable counts corresponded with those on the growth of strain AS7, which confirmed the key role of the QS in the spoilage of turbot.
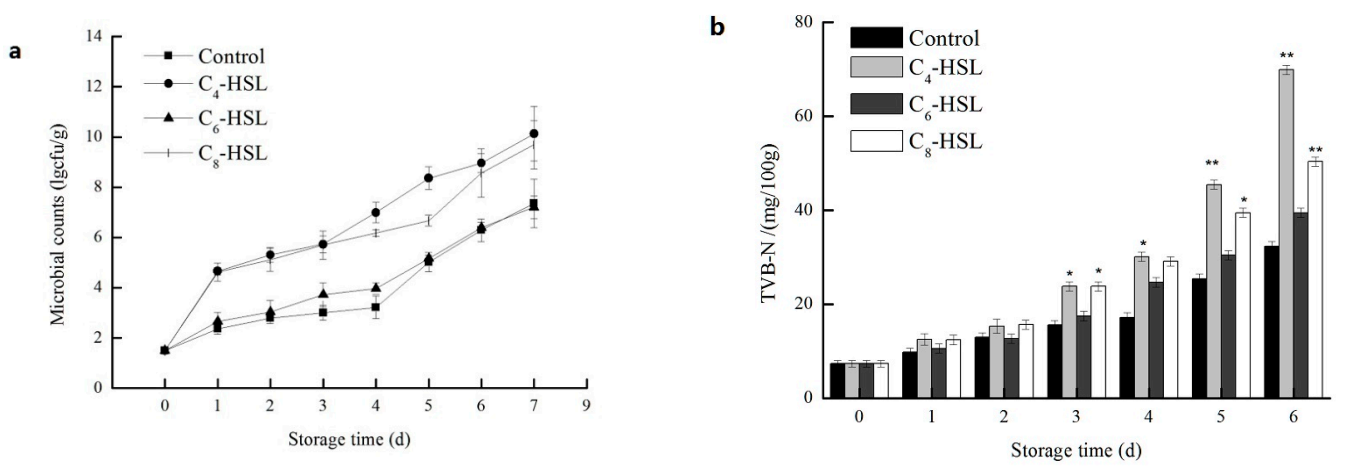

Figure 6. The effects of $\mathrm{C}_{4}-\mathrm{HSL}(20 \mu \mathrm{M}), \mathrm{C}_{6}-\mathrm{HSL}(20 \mu \mathrm{M})$ and $\mathrm{C}_{8}-\mathrm{HSL}(20 \mu \mathrm{M})$ on (a) microbial counts; and (b) TVB-N production in turbot blocks stored at $4{ }^{\circ} \mathrm{C}$. Data were presented as the mean \pm standard deviation $\left(n=6\right.$; ${ }^{*} p<0.05$; $\left.{ }^{* *} p<0.01\right)$.

\section{Conclusions}

In conclusion, $A$. sobria strain AS7 showed QS activity with the production of $\mathrm{C}_{4}-\mathrm{HSL}, \mathrm{C}_{6}-\mathrm{HSL}$, $\mathrm{C}_{8}-\mathrm{HSL}, \mathrm{C}_{10}-\mathrm{HSL}$ and $\mathrm{C}_{12}-\mathrm{HSL}$ according to GC-MS analysis. Meanwhile, the kinetics of AHL production were performed in our laboratory at present. The influences of different $\mathrm{pH}, \mathrm{NaCl}$ concentrations and carbon sources on the production of AHLs were also studied. Siderophore production of AS7 could chelate the iron from the environment and build an environment of low iron, which could restrain other microbial growth, then make it into specific spoilage organisms (SSO) and accelerated spoilage. QS was involved in the spoilage of turbot. Our future studies will concentrate on the quantities of AHLs produced in response to changes in the environment, and the actual environment in foods should be responsible for stimulation and inhibition of AHLs production. There might be significance for the food industry to control food spoilage using an anti-QS strategy.

Acknowledgments: This study was supported by a grant from the National Natural Science Foundation of China (No. 31471639, No. 31301572), the China Postdoctoral Science Foundation (No. 2014M552302), the Chongqing Postdoctoral Special Foundation (No. Xm2014041), and the Specialized Research Fund on the Priority Area for the Doctoral Program of the Higher Education of China (20113326130001).

Author Contributions: Tingting $\mathrm{Li}$ and Jianrong Li conceived and designed the experiments; Tingting Li performed the experiments; Tingting Li and Fangchao Cui analyzed the data; Fengling Bai and Guohua Zhao contributed reagents/materials/analysis tools; Tingting Li and Fangchao Cui wrote the paper.

Conflicts of Interest: The authors declare no conflict of interest. 


\section{Abbreviations}

The following abbreviations are used in this manuscript:

$\begin{array}{ll}\text { APPA } & \text { Ala-Phe-Pro-ARYLAMIDASE } \\ \text { H2S } & \text { H2S PRODUCTION } \\ \text { BGLU } & \text { BETA-GLUCOSIDASE } \\ \text { ProA } & \text { L-Proline ARYLAMIDASE } \\ \text { SAC } & \text { SACCHAROSE/SUCROSE } \\ \text { ILATk } & \text { L-LACTATE alkalinisation } \\ \text { GlyA } & \text { Glycine ARYLAMIDASE } \\ \text { O129R } & \text { O/129 RESISTANCE (comp.vibrio.) } \\ \text { ADO } & \text { ADONITOL } \\ \text { BNAG } & \text { BETA-N-ACETYL-GLUCOSAMINIDASE } \\ \text { dMAL } & \text { D-MALTOSE } \\ \text { LIP } & \text { LIPASE } \\ \text { dTAG } & \text { D-TAGATOSE } \\ \text { AGLU } & \text { ALPHA-GLUCOSIDASE } \\ \text { ODC } & \text { ORNITHINE DECARBOXYLASE } \\ \text { GGAA } & \text { Glu-Gly-Arg-ARYLAMIDASE } \\ \text { PyrA } & \text { L-Pyrrolydonyl-ARYLAMIDASE } \\ \text { AGLTp } & \text { Glutamyl Arylamidase pNA } \\ \text { dMAN } & \text { D-MANNITOL } \\ \text { PLE } & \text { PALATINOSE } \\ \text { dTRE } & \text { D-TREHALOSE } \\ \text { SUCT } & \text { SUCCINATE alkalinisation } \\ \text { LDC } & \text { LYSINE DECARBOXYLASE } \\ \text { IMLTa } & \text { L-MALATE assimilation } \\ \text { IARL } & \text { L-ARABITOL } \\ \text { dGLU } & \text { D-GLUCOSE } \\ \text { dMNE } & \text { D-MANNOSE } \\ \text { TyrA } & \text { Tyrosine ARYLAMIDASE } \\ \text { CIT } & \text { CITRATE (SODIUM) } \\ \text { NAGA } & \text { Beta-N-ACETYL-GALACTOSAMINIDASE } \\ \text { IHISa } & \text { L-HISTIDINE assimilation } \\ \text { ELLM } & \text { ELLMAN } \\ \text { dCEL } & \text { D-CELLOBIOSE } \\ \text { GGT } & \text { GAMMA-GLUTAMYL-TRANSFERASE } \\ \text { BXYL } & \text { BETA-XYLOSIDASE } \\ \text { URE } & \text { UREASE } \\ \text { MNT } & \text { MALONATE } \\ \text { AGAL } & \text { ALPHA-GALACTOSIDASE } \\ \text { CMT } & \text { COURMARATE } \\ \text { ILATa } & \text { L-LACTATE assimilation } \\ \text { BGAL } & \text { BETA-GALACTOSIDASE } \\ \text { OFF } & \text { FERMENTATION/GLUCOSE } \\ \text { BAIap } & \text { BETA-Alanine arylamidase pNA } \\ \text { dSOR } & \text { D-SORBITOL } \\ \text { 5KG } & \text { 5-KETO-D-GLUCONATE } \\ \text { PHOS } & \text { PHOSPHATASE } \\ \text { BGUR } & \text { BETA-GLUCORONIDASE } \\ & \end{array}$

\section{References}

1. Yunos, N.Y.M.; Tan, W.S.; Koh, C.L.; Sam, C.K.; Mohamad, N.I.; Tan, P.W.; Adrian, T.G.S.; Yin, W.F.; Chan, K.G. Pseudomonas cremoricolorata strain ND07 produces $\mathrm{N}$-acyl homoserine lactones as quorum sensing molecules. Sensors 2014, 14, 11595-11604. [CrossRef] [PubMed]

2. Schuster, M.; Joseph Sexton, D.; Diggle, S.P.; Peter Greenberg, E. Acyl-homoserine lactone quorum sensing: From evolution to application. Ann. Rev. Microbiol. 2013, 67, 43-63. [CrossRef] [PubMed]

3. Kalia, V.C. Quorum sensing inhibitors: An overview. Biotechnol. Adv. 2013, 31, 224-245. [CrossRef] [PubMed]

4. Wang, H.H.; Ye, K.P.; Zhang, Q.Q.; Dong, Y.; Xu, X.L.; Zhou, G.H. Biofilm formation of meat-borne Salmonella enterica and inhibition by the cell-free supernatant from Pseudomonas aeruginosa. Food Control 2013, 32, 650-658. [CrossRef]

5. Hense, B.A.; Kuttler, C.; Müller, J.; Rothballer, M.; Hartmann, A.; Kreft, J.U. Does efficiency sensing unify diffusion and quorum sensing? Nat. Rev. Microbiol. 2007, 5, 230-239. [CrossRef] [PubMed] 
6. Hartmann, A.; Rothballer, M.; Hense, B.A.; Schröder, P. Bacterial quorum sensing compounds are important modulators of microbe-plant interactions. In The Plant Microbiome and Its Importance for Plant and Human Health; Frontiers E-books: Lausanne, Switzerland, 2015; p. 41.

7. De Kievit, T.R.; Iglewski, B.H. Bacterial quorum sensing in pathogenic relationships. Infect. Immun. 2000, 68, 4839-4849. [CrossRef] [PubMed]

8. Jahid, I.K.; Mizan, M.F.R.; Ha, A.J.; Ha, S.D. Effect of salinity and incubation time of planktonic cells on biofilm formation, motility, exoprotease production, and quorum sensing of Aeromonas hydrophila. Food Microbiol. 2015, 49, 142-151. [CrossRef] [PubMed]

9. Rani, S.; Kumar, A.; Malik, A.K.; Schmitt-Kopplin, P. Occurrence of $N$-acyl homoserine lactones in extracts of bacterial strain of Pseudomonas aeruginosa and in sputum sample evaluated by gas chromatography-mass spectrometry. Am. J. Anal. Chem. 2011, 2, 294. [CrossRef]

10. Swift, S.; Winson, M.K.; Chan, P.F.; Bainton, N.J.; Birdsall, M.; Reeves, P.J.; Rees, C.E.D.; Chhabra, S.R.; Hill, P.J.; Throup, J.P.; et al. A novel strategy for the isolation of luxl homologues: Evidence for the widespread distribution of a LuxR: Luxl superfamily in enteric bacteria. Mol. Microbiol. 1993, 10, 511-520. [CrossRef] [PubMed]

11. Gram, L.; Christensen, A.B.; Ravn, L.; Molin, S.; Givskov, M. Production of acylated homoserine lactones by psychrotrophic members of the Enterobacteriaceae isolated from foods. Appl. Environ. Microbiol. 1999, 65, 3458-3463. [PubMed]

12. Ravn, L.; Christensen, A.B.; Molin, S.; Givskov, M.; Gram, L. Methods for detecting acylated homoserine lactones produced by Gram-negative bacteria and their application in studies of AHL-production kinetics. J. Microbiol. Methods 2001, 44, 239-251. [CrossRef]

13. Shaw, P.D.; Ping, G.; Daly, S.L.; Cha, C.; Cronan, J.E.; Rinehart, K.L.; Farrand, S.K. Detecting and characterizing $\mathrm{N}$-acyl-homoserine lactone signal molecules by thin-layer chromatography. Proc. Natl. Acad. Sci. USA 1997, 94, 6036-6041. [CrossRef] [PubMed]

14. Ortori, C.A.; Dubern, J.F.; Chhabra, S.R.; Cámara, M.; Hardie, K.; Williams, P.; Barrett, D.A. Simultaneous quantitative profiling of $\mathrm{N}$-acyl-L-homoserine lactone and 2-alkyl-4 $(1 \mathrm{H})$-quinolone families of quorum-sensing signaling molecules using LC-MS/MS. Anal. Bioanal. Chem. 2011, 399, 839-850. [CrossRef] [PubMed]

15. Zhu, S.; Wu, H.; Zeng, M.; Liu, Z.; Wang, Y. The involvement of bacterial quorum sensing in the spoilage of refrigerated Litopenaeus vannamei. Int. J. Food Microbiol. 2015, 192, 26-33. [CrossRef] [PubMed]

16. Chen, J.; Zhu, N.; Kong, L.; Bei, Y.; Zheng, T.; Ding, X.; He, Z. First case of soft shell disease in Chinese soft-shelled turtle (Trionyx sinens) associated with Aeromonas sobria-A. veronii complex. Aquaculture 2013, 406, 62-67. [CrossRef]

17. Majtán, J.; Černy, J.; Ofúkaná, A.; Takáč, P.; Kozánek, M. Mortality of therapeutic fish Garra rufa caused by Aeromonas sobria. Asian Pac. J. Trop. Biomed. 2012, 2, 85-87. [CrossRef]

18. Stano, F.; Brindicci, G.; Monno, R.; Rizzo, C.; Ghezzani, F.; Carbonara, S.; Guaglianone, E.; Donelli, G.; Monno, L. Aeromonas sobria sepsis complicated by rhabdomyolysis in an HIV-positive patient: Case report and evaluation of traits associated with bacterial virulence. Int. J. Infect. Dis. 2009, 13, e113-e118. [CrossRef] [PubMed]

19. Namdari, H.; Bottone, E.J. Aeromonas species: Pathogens of aquatic inhabitants with a human host range. Clin. Microbiol. Newsl. 1991, 13, 113-116. [CrossRef]

20. Jahid, I.K.; Lee, N.Y.; Kim, A.; Ha, S.D. Influence of glucose concentrations on biofilm formation, motility, exoprotease production, and quorum sensing in Aeromonas hydrophila. J. Food Prot. 2013, 76, $239-247$. [CrossRef] [PubMed]

21. Chu, W.; Liu, Y.; Jiang, Y.; Zhu, W.; Zhuang, X. Production of N-acyl homoserine lactones and virulence factors of waterborne Aeromonas hydrophila. Indian J. Microbiol. 2013, 53, 264-268. [CrossRef] [PubMed]

22. Khajanchi, B.K.; Sha, J.; Kozlova, E.V.; Erova, T.E.; Suarez, G.; Sierra, J.C.; Popov, V.L.; Horneman, A.J.; Chopra, A.K. N-acylhomoserine lactones involved in quorum sensing control the type VI secretion system, biofilm formation, protease production, andin vivo virulence in a clinical isolate of Aeromonas hydrophila. Microbiology 2009, 155, 3518-3531. [CrossRef] [PubMed]

23. Hassan, R.A.; Khattab, M.A.; Rohman, R.Z.A. Performance of Vitek-2 System for Detection of Inducible Clindamycin Resistance among Clinical Isolates of Staphylococci in Comparison to the D-Test. Egypt. J. Med. Microbiol. (EJMM) 2015, 24, 99-104.

24. Chen, J.W.; Koh, C.L.; Sam, C.K.; Yin, W.F.; Chan, K.G. Short chain N-acyl homoserine lactone production by soil isolate Burkholderia sp. strain A9. Sensors 2013, 13, 13217-13227. [CrossRef] [PubMed] 
25. Liu, M.; Gray, J.M.; Griffiths, M.W. Occurrence of proteolytic activity and N-acyl-homoserine lactone signals in the spoilage of aerobically chill-stored proteinaceous raw foods. J. Food Prot. 2006, 69, 2729-2737. [PubMed]

26. Zimmer, B.L.; May, A.L.; Bhedi, C.D.; Dearth, S.P.; Prevatte, C.W.; Pratte, Z.; Campagna, S.R.; Richardson, L.L. Quorum sensing signal production and microbial interactions in a polymicrobial disease of corals and the coral surface mucopolysaccharide layer. PLoS ONE 2014, 9, e108541. [CrossRef] [PubMed]

27. Schwyn, B.; Neilands, J.B. Universal chemical assay for the detection and determination of siderophores. Anal. Biochem. 1987, 160, 47-56. [CrossRef]

28. Herbert, R.A.; Hendrie, M.S.; Gibson, D.M.; Shewan, J.M. Bacteria active in the spoilage of certain sea foods. J. Appl. Bacteriol. 1971, 34, 41-50. [CrossRef] [PubMed]

29. Saitou, N.; Nei, M. The neighbor-joining method: A new method for reconstructing phylogenetic trees. Mol. Biol. Evol. 1987, 4, 406-425. [PubMed]

30. Felsenstein, J. Confidence limits on phylogenies: An approach using the bootstrap. Evolution 1985, 783-791. [CrossRef]

31. Tamura, K.; Nei, M.; Kumar, S. Prospects for inferring very large phylogenies by using the neighbor-joining method. Proc. Natl. Acad. Sci. USA 2004, 101, 11030-11035. [CrossRef] [PubMed]

32. Cha, C.; Gao, P.; Chen, Y.C.; Shaw, P.D.; Farrand, S.K. Production of acyl-homoserine lactone quorum-sensing signals by gram-negative plant-associated bacteria. Mol. Plant-Microbe Interact. 1998, 11, 1119-1129. [CrossRef] [PubMed]

33. McClean, K.H.; Winson, M.K.; Fish, L.; Taylor, A.; Chhabra, S.R.; Camara, M.; Daykin, M.; Lamb, J.H.; Swift, S.; Bycroft, B.W.; et al. Quorum sensing and Chromobacterium violaceum: Exploitation of violacein production and inhibition for the detection of N-acylhomoserine lactones. Microbiology 1997, 143, 3703-3711. [CrossRef] [PubMed]

34. Medina-Martinez, M.S.; Uyttendaele, M.; Demolder, V.; Debevere, J. Influence of food system conditions on N-acyl-L-homoserine lactones production by Aeromonas spp. Int. J. Food Microbiol. 2006, 112, $244-252$. [CrossRef] [PubMed]

35. Flodgaard, L.R.; Christensen, A.B.; Molin, S.; Givskov, M.; Gram, L. Influence of food preservation parameters and associated microbiota on production rate, profile and stability of acylated homoserine lactones from food-derived Enterobacteriaceae. Int. J. Food Microbiol. 2003, 84, 145-156. [CrossRef]

36. Fuqua, C.; Parsek, M.R.; Greenberg, E.P. Regulation of gene expression by cell-to-cell communication: Acyl-homoserine lactone quorum sensing. Ann. Rev. Genet. 2001, 35, 439-468. [CrossRef] [PubMed]

37. Cataldi, T.R.; Bianco, G.; Palazzo, L.; Quaranta, V. Occurrence of N-acyl-L-homoserine lactones in extracts of some Gram-negative bacteria evaluated by gas chromatography-mass spectrometry. Anal. Biochem. 2007, 361, 226-235. [CrossRef] [PubMed]

38. Chan, K.G.; Puthucheary, S.D.; Chan, X.Y.; Yin, W.F.; Wong, C.S.; Too, W.S.S.; Chua, K.H. Quorum sensing in Aeromonas species isolated from patients in Malaysia. Curr. Microbiol. 2011, 62, 167-172. [CrossRef] [PubMed]

39. Gram, L.; Ravn, L.; Rasch, M.; Bruhn, J.B.; Christensen, A.B.; Givskov, M. Food spoilage-Interactions between food spoilage bacteria. Int. J. Food Microbiol. 2002, 78, 79-97. [CrossRef]

40. Gram, L. The influence of substrate on siderophore production by fish spoilage bacteria. J. Microbiol. Methods 1996, 25, 199-205. [CrossRef]

41. Bruhn, J.B.; Christensen, A.B.; Flodgaard, L.R.; Nielsen, K.F.; Larsen, T.O.; Givskov, M.; Gram, L. Presence of acylated homoserine lactones (AHLs) and AHL-producing bacteria in meat and potential role of AHL in spoilage of meat. Appl. Environ. Microbiol. 2004, 70, 4293-4302. [CrossRef] [PubMed]

42. Zhang, C.; Zhu, S.; Jatt, A.N.; Zeng, M. Characterization of N-acyl homoserine lactones (AHLs) producing bacteria isolated from vacuum-packaged refrigerated turbot (Scophthalmus maximus) and possible influence of exogenous AHLs on bacterial phenotype. J. Gen. Appl. Microbiol. 2016, 62, 60-67. [CrossRef] [PubMed]

43. Christensen, A.B.; Riedel, K.; Eberl, L.; Flodgaard, L.R.; Molin, S.; Gram, L.; Givskov, M. Quorum-sensing-directed protein expression in Serratia proteamaculans B5a. Microbiology 2003, 149, 471-483. [CrossRef] [PubMed]

(C) 2016 by the authors; licensee MDPI, Basel, Switzerland. This article is an open access article distributed under the terms and conditions of the Creative Commons Attribution (CC-BY) license (http://creativecommons.org/licenses/by/4.0/). 